\title{
PENGEMBANGAN MODUL PEMBELAJARAN PADA KOMPETENSI AUTOCAD SISWA SMK
}

\author{
Afriandi Siahaan \\ Guru SMK Negeri 1 Lubuk Pakam, Sumatera Utara \\ Afriandi.siahaan@gmail.com
}

\begin{abstract}
Abstrak: Penelitian ini bertujuan (1) menghasilkan modul pembelajaran autocad jurusan teknik gambar bangunan siswa tingkat dua di SMK Negeri 1 Lubuk Pakam, (2) melihat efektifitas modul hasil pengembangan untuk pembelajaran Autocad jurusan Teknik Gambar Bangunan siswa tingkat dua SMK Negeri 1 Lubuk Pakam. Metode penelitian yang digunakan adalah Research and Development. Pengembangan bahan ajar dilakukan dengan dilakukan dengan menggunakan model Dick and Carey, pengembangan modul mengacu pada teori Mourdel. Pengumpulan Data menggunakan angket, observasi, interview, dokumentasi, dan data hasil belajar menggunakan pretes dan postes. Analisis data observasi, angket, interview menggunakan pendekatan kualitatif sedangkan analisis data hasil belajar dilakukan dengan menggunakan analisis kuantitatif. Untuk melihat efektifitas pembelajaran dengan menggunakan modul dilakukan dengan uji $t$ : antara data hasil belajar menggunakan modul hasil pengembangan dengan pembelajaran metode konvensional. Subjek penelitian adalah 2 orang guru, 31 orang siswa kelas XI Teknik Gambar Bangunan A sebagai kelas modul (eksperimen), dan 31 orang siswa kelas XI Teknik Gambar Bangunan B SMK Negeri 1 Lubuk Pakam sebagai kelas metode konvensional.
\end{abstract}

Kata Kunci: Pengembangan modul pembelajaran, hasil belajar autocad

Abstract: This research was aimed to (1) produce the module of study of autocad of technique majors draw the student building mount two in SMK Negeri 1 Lubuk Pakam, (2) see the effektivitas module of result of development for the study of autocad of technique majors draws the student building mount two in SMK Negeri 1 Lubuk Pakam. The research method used was Research and Development model by Borg \& Gall which is known as $R \& D$ Cycle. To develop the instructional material of the modul used Mourdel's model. The data collecting instrument were field study, observation, interview and questionnaire as long as development activity and post test to know the affect of the modul by using objectif test. To see the effekticnes of modul to haiger the instructional outcomes or mastering the competency done by differentiating outcomes between modul group and convensional method group. The differentiation analisis by using t-test to find out significances. The subject research was 2 teachers, 31 students of XI TGB A as class modul (Class experiment), and 31 students of XI TGB B as class convensional (Class control) class at SMK Negeri 1 Lubuk Pakam.

Keywords: The Development of Instructional Modul, the result of learning Autocad

\section{PENDAHULUAN}

Secara khusus tujuan kompetensi keahlian teknik gambar bangunan adalah membekali peserta didik dengan keterampilan, pengetahuan, dan sikap agar kompeten: (a) melakukan pekerjaan sebagai drafter/juru gambar dalam pekerjaan perencanaan bangunan, (b) melakukan pekerjaan sebagai drafter/juru gambar dalam pekerjaan pelaksanaan bangunan, (c) melakukan pekerjaan jasa penggambaran bangunan secara mandiri/berwiraswasta di studio gambar.
Untuk dapat memenuhi tujuan tersebut Autocad adalah salah satu mata diklat produktif yang harus dikuasai siswa SMK Kompetensi Keahlian Teknik Bangunan, yang bergelut dengan gambar-gambar dan menuntut ketelitian dalam ukuran, diharapkan dengan ketelitian tersebut gambar dapat mewakili suatu objek yang akan dikerjakan.

Untuk menyiapkan lulusannya menjadi tenaga produktif, adaptif, normatif SMK Negeri 1 Lubuk Pakam setelah melakukan berbagai hal antara lain: (1) melengkapi peralatan laboratorium Autocad berupa komputer dan 
peralatan multimedia, (2) mengirim guru praktek untuk mengikuti diklat kompetensi.

Berdasarkan hasil studi pendahuluan di SMK Negeri 1 Lubuk Pakam di dapat hasil angket analisis kebutuhan yang disebarkan oleh guru dan siswa diperoleh kesimpulan sebagai berikut; (1) Sebagian besar guru maupun siswa $(81 \%)$ menyatakan belum mengenal modul pembelajaran, hanya sebagian kecil $(19 \%)$ guru dan siswa yang menyatakan telah mengenal modul, (2) Sebagian besar guru (83\%) menyatakan tidak menggunakan modul pembelajaran dalam proses pembelajaran dan siswa $(100 \%)$ menyatakan tidak pernah mengguanakan modul, (3) Sebagian besar guru $(83 \%)$ menyatakan memerlukan modul pembelajaran dalam proses pembelajaran dan seluruh siswa (100\%) menyatakan memerlukan modul pembelajaran dalam proses pembelajaran

Pengembangan pengalaman belajar perlu untuk dikembangkan melalui upaya penyediaan sarana pendidikan, metode pengajaran yang relevan serta strategi pembelajaran yang tepat. Proses pembelajaran yang dirancang dengan baik akan meningkatkan kualitas hasil belajar. Variabel yang mempengaruhi perilaku belajar adalah kondisi pembelajaran, metode pembelajaran dan hasil belajar.

Berbagai strategi, metode, serta model pembelajaran telah ditemukan dan telah diterapkan dan dibelajarkan kepada calon guru maupun guru, namun kenyataan sampai saat ini secara umum guru masih menggunakan cara lama yang terfokus pada metode ceramah dan tanya jawab. Penyajian materi pelajaran dilakukan secara klasikal, kurang memperhatikan kemampuan individu siswa, bersifat teori dan kurang memperhatikan keseimbangan antara pengetahuan dan keterampilan. Perbaikan kualitas pembelajaran dapat dimulai dari rancangan pembelajaran karena melalui perancangan akan dilakukan langkah-langkah sistematis untuk memberikan pengalaman belajar kepada siswa sehingga tujuan pembelajaran dapat tercapai. Dalam perancangan dan pelaksanaan pembelajaran di SMK Teknologi, beberapa variabel seperti ketersediaan alat dan bahan praktek, ketersediaan buku, dan kurikulum yang menentukan kualitas pembelajaran harus diterima sebagaimana adanya oleh guru. Tujuan mata diklat umpamanya, tidak dapat dimanipulasi oleh guru karena sudah ditetapkan dalam kurikulum. Demikian pula halnya dengan karakterisik individu dan mata diklat, keterbatasan sumber-sumber belajar dan keterbatasan peralatan praktek. Variabel yang penting dari semua variabel ini adalah sumber belajar, karena sumber belajar dapat dimanipulasi agar dapat mempengaruhi perubahan tingkah laku dari berbagai karakteristik siswa yang berbda-beda. Karakteristik penting dari sumber belajar antara lain adalah ketersediaan informasi yang lengkap berkaitan dengan pengetahuan yang hendak dikuasai sehingga siswa memiliki pengetahuan dan keterampilan.

Tren desain bangunan dewasa ini telah beralih kepenggunaan teknologi komputer karena mampu menutupi kelemahan teknik konvensional yang umum digunakan, terutama dalam hal menampilkan efek realistik dalam penyajiannya. Untuk itu dibutuhkan sebuah sarana yang tepat untuk lebih menunjang penyampaian gagasan yang akan dipresentasikan. Autocad merupakan program yang sangat andal yang dipergunakan untuk menolah gambar teknik pada bidang desain bangunan, mesin, furniture, dan pemetaan (Sugianto, 2010:1) Perkembangan Autocad sangat cepat, hampir setiap tahun Launching. Pada setiap versinya Autocad memberikan banyak kemudahan dalam penyajian gambar teknik. Autocad merupakan salah satu produk Computer Aided Design (CAD) yang paling banyak dipergunakan dewasa ini. CAD adalah alat bantu merancang menggunakan komputer dengan tujuan untuk menghasilkan output rancangan yang memiliki tingkat akurasi tinggi dan dirancang dalam waktu singkat.

Autocad merupakan salah satu produk Computer Adided Desaign (CAD) yang paling banyak digunakan dewasa ini. Autocad adalah alat bantu merancang, menggunakan komputer dengan tujuan untuk menghasilkan output rancangan yang memiliki tingkat akurasi tinggi dan di rancang dalam waktu singkat.

Defenisi terbaru teknologi pendidikan AECT (2004: 21-22) adalah studi dan etika praktek dalam upaya memfasilitasi pembelajaran dan meningkatkan kinerja dengan cara menciptakan, menggunakan atau memanfaatkan dan mengelola proses dan sumber-sumber teknologi yang tepat. Dengan demikian tujuannya masih tetap untuk memfasilitasi pembelajaran agar lebih efektif, efisien dan menyenangkan serta meningkatkan kinerja.

Berdasarkan definisi-definisi di atas dapat disimpulkan bahwa: (1) teknologi 
pembelajaran adalah suatu disiplin ilmu atau bidnag garapan dan profesi, (2) istilah teknologi pembelajaran dipakai bergantian dengan istilah teknologi pendidikan, (3) tujuan utama teknologi pembelajaran adalah (a) untuk memecahkan masalah belajar atau memfasilitas pembelajaran; dan (b) untuk meningkatkan kinerja, (4) menggunakan pendekatan sistemik (holistic atau menyeluruh), (5) kawasan teknologi pembelajaran dapat meliputi kegiatan yang berkaitan dengan analisis, desain, pengembangan, pemanfaatan, pengelolaan, implementasi dan evaluasi baik proses-proses maupun sumber-sumber belajar, (6) teknologi pembelajaran tidak hanya bergerak di dunia pendidikan tapi juga dalam semua aktivitas manusia (seperti perusahaan, keluarga, organisasi masyarakat, dll) sejauh berkaitan dengan upaya memecahkan masalah belajar dan peningkatan kinerja, (7) teknologi diartikan secara luas, bukan hanya teknologi fisik (hardtech) tapi juga teknologi lunak (softtech).

Teknologi pembelajaran sebagai suatu profesi berakar dari penelitian, teori, dan praktek. Suatu profesi harus mempunyai landasan pengetahuan yang menunjang praktek. Tiap kawasan teknologi pembelajaran mengandung kerangka pengetahuan yang didasarkan pada hasil penelitian dan pengalaman. Hubungan antara teori dan praktek semakin mantap dengan matangnya bidang garapan. Teori terdiri dari konsep, bangunan (konstruk), prinsip, dan proposisi yang member sumbangan terhadap khasanah pengetahuan. Sedangkan praktek merupakan penerapan pengetahuan tersebut dalam memecahkan permasalahan. Dalam teknologi pembelajaran baik teori maupun praktek, banyak menggunakan model.

Menurut Nasution (2008:205) modul merupakan suatu unit lengkap yang berdiri sendiri dan tertulis atas suatu rangkaian kegiatan belajar yang disusun untuk membantu warga belajr mencapai sejumlah tujuan yang dirumuskan secara khusus dan jelas. Modul merupakan suatu unit program belajar mengajar terkecil yang secara rinci menggariskan: (1) petunjuk penggunaan yang memberi penjelasan tentang cara warga belajar menggunakan modul, (2) tujuan penggunaan modul, berisi tujuan yang akan dicapai setelah mempelajari modul, (3) materi pelajaran yang akan dicapai warga belajar, (4) lembar kegiatan warga belajar, berisikan kegiatan yang akan dilakukan baik teori maupun mengadakan percobaan, dan
(5) latihan, berisikan tes yang digunakan untuk menilai ketercapaian tujuan yang telah dirumuskan. Modul adalah suatu alat pembelajaran yang didasrkan pada metode belajar sendiri yang dilakukan dengan seperangkat pembelajaran yang berisikan: petunjuk melakukan, pengetahuan yang bersifat teroi dan praktek dan evaluasi.

Pengajaran modul juga memberi kesempatan bagi peserta didik untuk belajar menurut cara masing-masing, menggunakan teknik yang berbeda-beda untuk memecahkan masalah tertentu berdasarkan latar belakang pengetahuan dan kebiasan masing-masing. Pengerjaan modul yang baik memberikan aneka ragam kegiatan instruksional.

Pembelajaran modul sebagai suatu pendekatan pembelajaran mandiri yang berfokuskan penguasaan kompetensi dari bahan kajian yang dipelajari peserta didik dengan waktu tertentu sesuai dengan potensi dan kondisinya. Pembelajaran modul memiliki fungsi untuk memastikan semua peserta didik menguasai kompetensi yang diharapkan dalam suatu materi ajar sebelum pindah ke materi ajar selanjutnya melalui pengajaran mandiri. Selain itu pembelajaran modul bertujuan untuk menjawab keragaman kecepatan belajar dari peserta didik agar mencapai suatu tingkat pencapaian kompetensi tertentu sesuai dengan tujuan pembelajaran yang telah disusun secara sistematis dan terstruktur.

Finch dan Crunkilton dalam Sibuea (2000) mengatakan modul pembelajaran dapat didefinisikan sebagai suatu paket serba lengkap yang mencakup serangkaian rencana pengalaman-pengalaman belajar yang dirancang untuk membantu siswa mencapai tujuan khusus. Oleh sebab itu modul harus yaitu: (1) ada bagian modul yang diisi sendiri oleh siswa dan tidak perlu bertanya kepada guru apa yang harus dikerjakan berikutnya, (2) dapat digunakan belajar sendiri sesuai dengan karakteristik siswa agar dapat maju sesuai kecepatan siswa, menerima penilaian kemajuan melalui masing-masing modul, fokus untuk mencapai tujuan khusus yang dapat diukur dalam tiap-tiap modul, (3) paket lengkap, (4) berisikan tujuan dan pengalaman belajar, (5) berisikan mekanisme untuk menilai apakah siswa sudah mencapai tujuan. Dalam mengembangkan modul ada 7 hal yang harus dipenuhi yaitu: (1) ada pendahuluan, (2) dinyatakan tujuan pelajaran, (3) dilakukan penilaian awal dan akhir (4) terdapat 
pengalaman belajar, (5) dituliskan sumber materi belajaran, dan (6) di uji coba.

Masalah dapat dirumuskan sebagai berikut: (1) apakah modul pembelajaran pada mata pelajaran autocad siswa kelas XI Teknik Gambar Bangunan SMK Negeri 1 Lubuk Pakam layak digunakan dalam proses pembelajaran? dan (2) apakah modul pembelajaran yang dikembangkan pada mata pelajaran autocad efektif dapat meningkastkan hasil belajar?

\section{METODE}

Penelitian ini dilaksanakan di SMK Negeri 1 Lubuk Pakam siswa kelas XI semester 4 Kompetensi Keahlian Teknik Gambar Bangunan. Pengembangan modul pembelajaran dilakukan merujuk pada langkah-langkah penelitian pengembangan model Borg and Gall , pengembangan bahan ajar merujuk pada Dick and Carey. Langkah-langkah yang dilakukan dalam pengembangan (Borg and Gall) adalah: (1) studi pendahuluan, (2) perencanaan dan penyusunan modul, (3) uji modul (validasi).

Instrument yang digunakan untuk mengumpulkan data yang dipergunakan pada penelitian pengembangan modul pembelajaran disesuaikan dengan tahapan penelitian yang dilakukan yaitu studi pendahuluan, perencanaan dan pengembangan, dan uji coba modul.

Studi Pendahuluan. Pada tahap ini, instrumen yang digunakan adalah angket dan observasi. Angket digunakan untuk mengetahui proses pembelajaran yang selama ini dilakukan, kemampuan guru dalam menerapkan modul dan pemahaman guru mengenai modul pembelajaran. Adapun kisi-kisi instrument angket untuk guru dapat dilihat pada tabel.

Angket juga diberikan kepada siswa untuk mengetahui kemampuan sisiwa untuk mengikuti modul pembelajaran yang dilakukan (Lampiran 7). Observasi dilakukan untuk mengetahui secara langsung sarana dan prasarana yang ada untuk mendukung modul pembelajaran yang akan dikembangkan.

Perencanaan dan Pengembangan. Pada tahap ini instrumen yang digunakan adalah angket dan tes hasil belajar. Angket diberikan kepada ahli materi pembelajaran, ahli desain pembelajaran. Kisi-kisi angket masing-masing instrumen dapat dilihat pada lampiran 9.

Uji Coba Utama. Pada tahap uji coba instrument yang digunakan adalah angket dan tes hasil belajar.
Angket. Angket diberikan kepada siswa untuk mengetahui keputusan siswa terhadap modul pembelajaran yang dikembangkan. Angket dibuat dalam skala 1 sampai 5 dengan kriteria 1 : sangat kurang, 2 : kurang baik, 3 : sedang, 4 : baik, 5 : sangat baik. Kisi-kisi angket instrumen angket dapat dilihat pada lampiran 10 .

Tes Hasil Belajar. Tes hasil belajar digunakan untuk melihat efektifitas penerapan modul pembelajaran dengan membandingkan nilai pretest dan posttest siswa. Bentuk tes hasil belajar yang digunakan terdiri dari 25 soal tes yang sudah valid mencakup kawasan kognitif C1 (mengingat), C2 (pemahaman), C3 (penerapan), C4 (analisis), C5 (evaluasi), C6 (membuat, menciptakan). Setiap jawaban yang benar diberi skor 1 (satu) dan yang salah diberi skor 0 (nol). Sebelum instrumen digunakan maka diteliti dulu kualitasnya melalui uji coba. Kualitas instrumen ditujukan oleh kesahian (validitas) dan keterandalannya (reliabilitas) dalam mengungkapkan apa yang akan dikur, taraf kesukaran soal, dan daya beda butir soal.

Pengujian Hipotesis. Untuk pengujian hipotesis penelitian ini dilakukan dengan menggunakan rumus uji-t

$$
\mathrm{t}_{\text {hitung }}=\frac{\overline{x_{1}}-\overline{x_{2}}}{\sqrt[s]{\frac{1}{n_{1}}}-\frac{1}{n_{2}}} \text { Sudjana,2002:239) }
$$

dengan

$$
S^{2}=\frac{\left(n_{1}-1\right) s_{1}^{2}+\left(n_{2}-1\right) s_{n}^{2}}{n_{1}+n-2}
$$

Keterangan :

$\mathrm{t}=$ harga perhitungan

$\bar{x}_{1}=$ skor rata-rata kelas eksperimen

$\bar{x}_{2}=$ skor rata-rata kelas control

$\mathrm{n}_{1} \quad=$ jumlah sampel pada kelas eksperimen

$\mathrm{n}_{2} \quad=$ jumlah sampel pada kelas kontrol

$S_{1}{ }^{2}=$ varian kelompok kelas eksperimen

$S_{2}{ }^{2}=$ varian kelompok kelas kontrol

$\mathrm{S} \quad=$ varians gabungan

\section{Hipotesis Statistik}

Sesuai dengan hipotesis penelitian yang telah diungkapkan, maka hipotesis statistiknya dapat dirumuskan sebagai berikut :

Ho $: \mu \mathrm{A}_{1}=\mu \mathrm{A}_{2}$

$\mathrm{Ha}: \mu \mathrm{A}_{1}>\mu \mathrm{A}_{2}$

Dengan kalimat dapat dituliskan :

Ha : Modul pembelajaran yang dikembangkan mampu meningkatkan hasil belajar autocad. 
Ho : Modul pembelajaran yang dikembangkan tidak mampu meningkatkan hasil belajar autocad.

Untuk melihat nilai keefektifan modul pembelajaran yang dieksperimenkan digunakan rumus perhitungan efektifitas berikut (Sugiyono, 2011 : 411):

$$
\mathrm{X}=\frac{\text { jumlahskor yang diperoleh }}{\text { jumlahskor ideal seluruh item }} \mathrm{X}
$$

$100 \%$

\section{HASIL PENELITIAN \\ Data Hasil Uji Coba Lapangan}

Uji coba lapangan dilaksanakan dengan terlebih dahulu memperbaiki kekurangankekurangan yang sudah ditemukan pada uji coba produk awal, perorangan dan uji coba kelompok kecil. Uji coba lapangan dilaksanakan di SMK Negeri 1 Lubuk Pakam Kelas XI Jurusan Teknik Gambar Bangunan yang berjumlah 62 orang siswa yang terdiri dari kelas A sebanyak 31 siswa dan kelas B senyak 31 siswa. Uji coba lapangan dilakukan di laboratorium computer yang dilengkapi komputer berjumlah 35 buah. Setiap siswa masing-masing menggunakan 1 unit komputer. Uji coba lapangan menghasilkan data-data yang nantinya akan mengukur kelayakan dari produk yang dikembangkan, serta untuk mengetahui manfaat produk tersebut bagi pemakainya.

Pada uji coba lapangan pada 62 siswa Jurusan teknik Gambar Bangunan SMK Negeri 1 Lubuk Pakam secara umum siswa menyatakan bahwa modul pembelajaran yang dikembangkan sangat baik, dan tidak terdapat masalah yang harus diperbaiki. Dengan demikian tidak diadakan revisi pada uji coba lapangan, yang berarti modul pembelajaran telah siap diuji keefektifannya. Hasil evaluasi uji coba lapangan dapat dilihat pada tabel 1 .

Tabel 1. Data Hasil Angket Setelah Uji Coba Lapangan

\begin{tabular}{|c|c|c|c|c|c|c|c|}
\hline \multirow{2}{*}{ Indikator } & \multicolumn{5}{|c|}{ Skor } & \multirow{2}{*}{ Rata-rata } & \multirow{2}{*}{ Kriteria } \\
\hline & 1 & 2 & 3 & 4 & 5 & & \\
\hline Kesesuaian Materi & & & 2 & 6 & 54 & $97,42 \%$ & Sangat Baik \\
\hline Kejelasan petunjuk belajar & & & 3 & 8 & 51 & $96,46 \%$ & Sangat Baik \\
\hline $\begin{array}{l}\text { Kemudahan memahami } \\
\text { kalimat pada teks }\end{array}$ & & & 7 & 8 & 47 & $95,17 \%$ & Sangat Baik \\
\hline Kemudahan memahami teks & & & 9 & 8 & 45 & $94,53 \%$ & Sangat Baik \\
\hline Ketepatan urutan penyajian & & & 9 & 9 & 44 & $94,2 \%$ & Sangat Baik \\
\hline Kecukupan latihan & & & 9 & 8 & 45 & $94,53 \%$ & Sangat Baik \\
\hline \multicolumn{6}{|c|}{ Rata-rata } & $95,39 \%$ & Sangat Baik \\
\hline Keindahan tampilan & & & 5 & 8 & 49 & $95,81 \%$ & Sangat Baik \\
\hline Keterangan teks & & & 6 & 9 & 47 & $95,17 \%$ & Sangat Baik \\
\hline Kualitas gambar & & 3 & 9 & 8 & 40 & $93,56 \%$ & Sangat Baik \\
\hline Keterbacaan teks & & 3 & 9 & 9 & 46 & $93,24 \%$ & Sangat Baik \\
\hline Mudah digunakan & & & 8 & 5 & 55 & $95,81 \%$ & Sangat Baik \\
\hline $\begin{array}{l}\text { Membantu lebih mudah } \\
\text { belajar }\end{array}$ & & & 7 & 6 & 53 & $95,81 \%$ & Sangat Baik \\
\hline \multicolumn{6}{|c|}{ Rat-rata } & $94,9 \%$ & Sangat Baik \\
\hline
\end{tabular}

Berdasarkan hasil data penilaian siswa terhadap modul pembelajaran yang dikembangkan yang ditunjukkan pada tabel 1 di atas dapat disimpulkan bahwa modul pembelajaran dalam kriteria "Sangat Baik" dengan presentase 94,9\%.

a. Analisis Uji Coba Kelompok Kecil

Tabel 2. Persentase Rata-rata Hasil Penilaian Pada Uji Coba Kelompok Kecil

\begin{tabular}{|c|c|c|c|}
\hline No. & Kategorisasi & $\begin{array}{c}\text { Persentase } \\
\text { rata-rata }\end{array}$ & Kriteria \\
\hline 1 & Aspek Materi Pembelajaran & $88,89 \%$ & Sangat Baik \\
\hline 2 & Aspek Kualitas Penyajian & $94,08 \%$ & Sangat Baik \\
\hline \multicolumn{2}{|c|}{ Rata-rata } & $91,49 \%$ & Sangat Baik \\
\hline
\end{tabular}


Tabel di atas menunjukkan persentase rata-rata dari hasil penilaian terhadap modul pembelajaran pada mata diklat autocad pada uji coba kelompok kecil di SMK Negeri 1 Lubuk Pakam terhadap aspek kualitas materi pembelajaran adalah sebesar $88,89 \%$ dan aspek kualitas penyajian sebesar $94,08 \%$, dan masing- msaing kategori sangat baik. Persentase ratarata dari hasil penilaian terhadap modul pembelajaran pada mata diklat autocad pada uji coba kelompok kecil terhadap aspek materi pembelajaran dan aspek kualitas penyajian dapat dilihat pada gambar berikut ini:

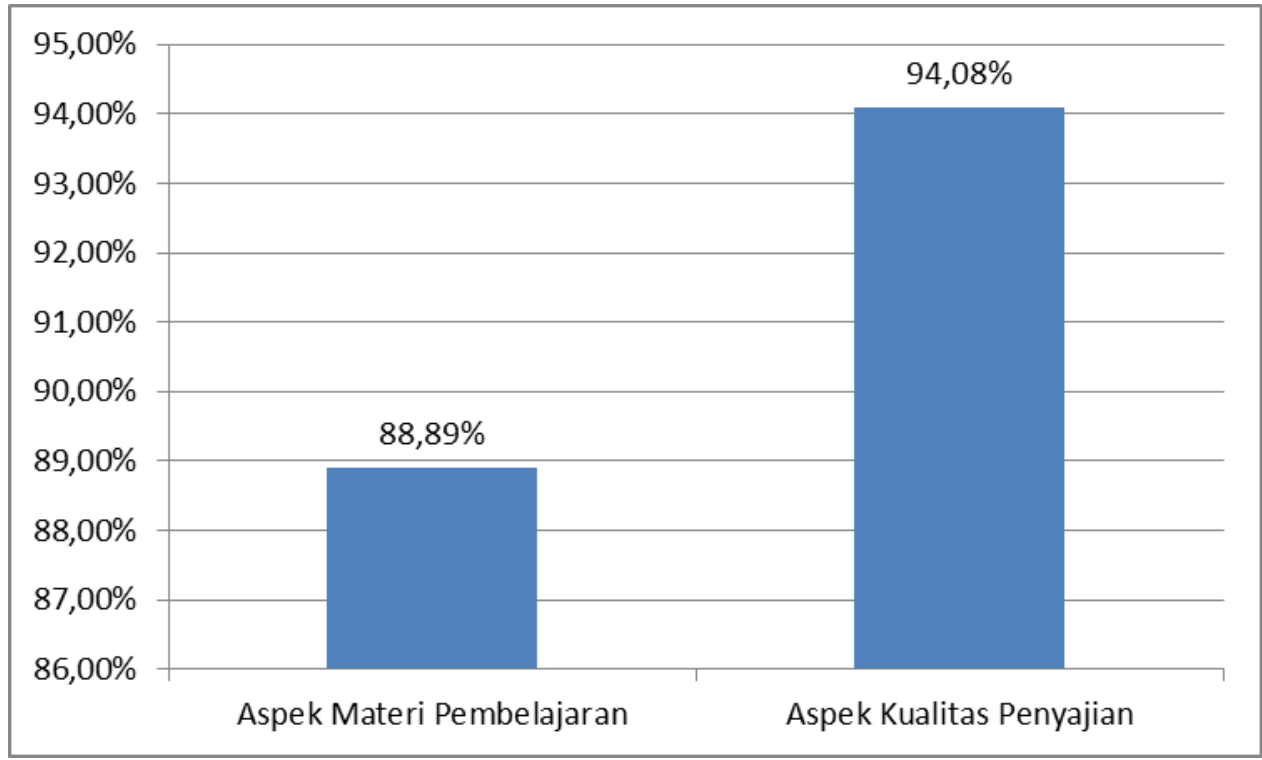

Gambar 1. Diagram presentase rata-rata hasil penilaian uji coba kelompok kecil

\section{b. Analisis Data uji Coba Lapangan}

Tabel 3. Persentase Rata-rata Hasil Penilaian Pada Uji Coba Lapangan

\begin{tabular}{|c|l|c|c|}
\hline No. & Kategorisasi & $\begin{array}{c}\text { Persentase } \\
\text { rata-rata }\end{array}$ & Kriteria \\
\hline 1 & Aspek Kualitas Materi & $95,39 \%$ & Sangat Baik \\
\hline 2 & Aspek Kualitas Penyajian & $94,9 \%$ & Sangat Baik \\
\hline \multicolumn{2}{|c|}{ Rata-rata } & $95,15 \%$ & Sangat Baik \\
\hline
\end{tabular}

Tabel di atas menunjukkan persentase rata-rata dari hasil penilaian terhadap modul pembelajaran pada mata diklat autocad pada uji coba lapangan di SMK Negeri 1 Lubuk Pakam terhadap aspek kualitas materi pembelajaran adalah sebesar $95,39 \%$ dan aspek kualitas penyajian sebesar $94,9 \%$ dan masing-msaing kategori sangat baik. Persentase rata-rata dari hasil penilaian terhadap modul pembelajaran pada mata diklat autocad pada uji coba kelompok kecil terhadap aspek materi pembelajaran dan aspek kualitas penyajian dapat dilihat pada gambar berikut ini: 


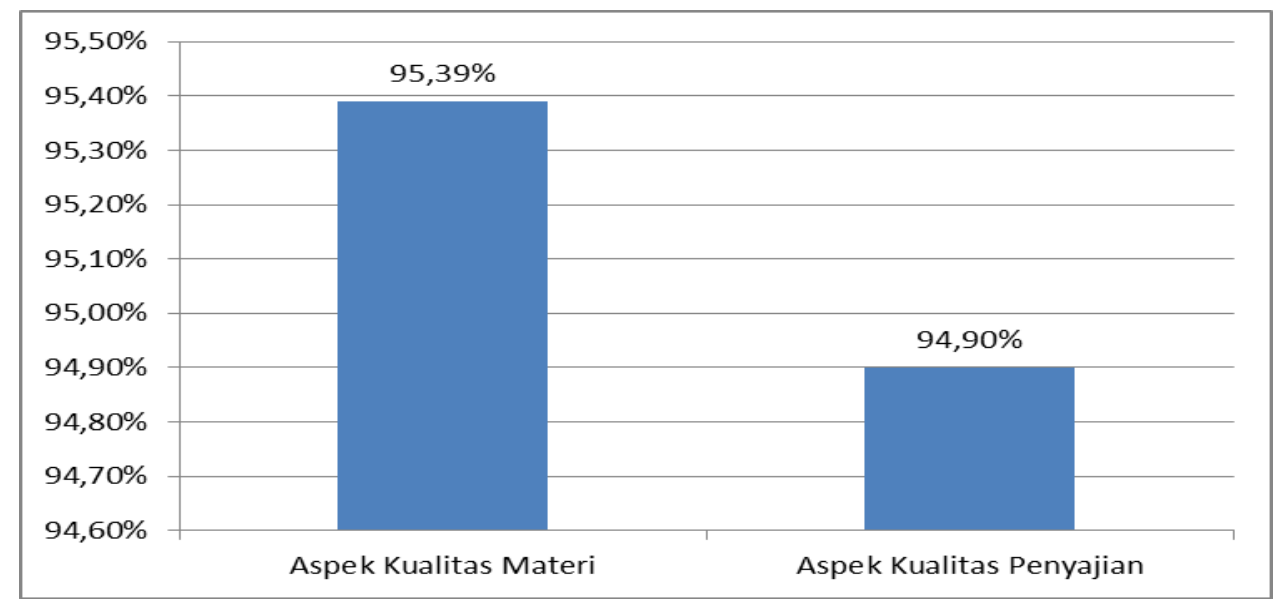

Gambar 2. Diagram presentase rata-rata hasil penilaian uji coba lapangan

Hasil penilaian terhadap modul pembelajaran mata diklat autocad pada uji coba lapangan 62 orang siswa semester genap Jurusan Teknik Gambar Bangunan SMK Negeri 1 Lubuk Pakam bahwa produk yang dikembangkan sangat baik atau layak digunakan dan tidak ada saran perbaikan yang disampaikan pada uji coba lapangan ini sehingga tidak dilakukan revisi.

\section{Hasil Penelitian Uji Keefektifan Produk \\ 1. Deskripsi Data Penelitian \\ a. Hasil Belajar Mata Pelajaran Autocad yang Dibelajarkan Dengan Menggunakan Modul Pembelajaran}

Berdasarkan penelitian yang telah dilakukan terhadap hasil belajar Autocad pada siswa yang dibelajarkan dengan modul pembelajaran, ditemukan bahwa skor hasil belajar siswa dari 31 responden tersebar pada rentang 60 - 100. Dari hasil perhitungan menunjukan bahwa skor terendah 60 dan tertinggi 100 , mean 82,19 , median 104,36 , dan standar deviasi 10,22. Secara lengkap gambaran tentang hasil belajar autocad siswa dengan menggunakan modul pembelajaran ditunjukkan pada tabel 4. berikut ini:

Tabel 4. Frekuensi Nilai Hasil Belajar yang Dibelajarkan Dengan Menggunakan Modul

\begin{tabular}{|c|c|c|c|}
\hline No. & Skor & Frekuensi & Frekuensi Relatif (\%) \\
\hline 1 & $61-64$ & 1 & 3,23 \\
\hline 2 & $65-68$ & 4 & 12,9 \\
\hline 3 & $69-72$ & 0 & 0 \\
\hline 4 & $73-76$ & 7 & 22,58 \\
\hline 5 & $77-80$ & 5 & 16,13 \\
\hline 6 & $81-84$ & 1 & 3,23 \\
\hline 7 & $85-88$ & 4 & 12,9 \\
\hline 8 & $89-92$ & 6 & 19,35 \\
\hline 9 & $93-96$ & 1 & 3,23 \\
\hline 10 & $97-100$ & 2 & 6,45 \\
\hline & Total & 31 & 100 \\
\hline
\end{tabular}

Tabel 4 menunjukkan data hasil belajar autocad siswa yang dibelajarkan dengan menggunakan modul. Selanjutnya di atas disusun dalam bentuk histogram seperti pada gambar 3 berikut ini: 


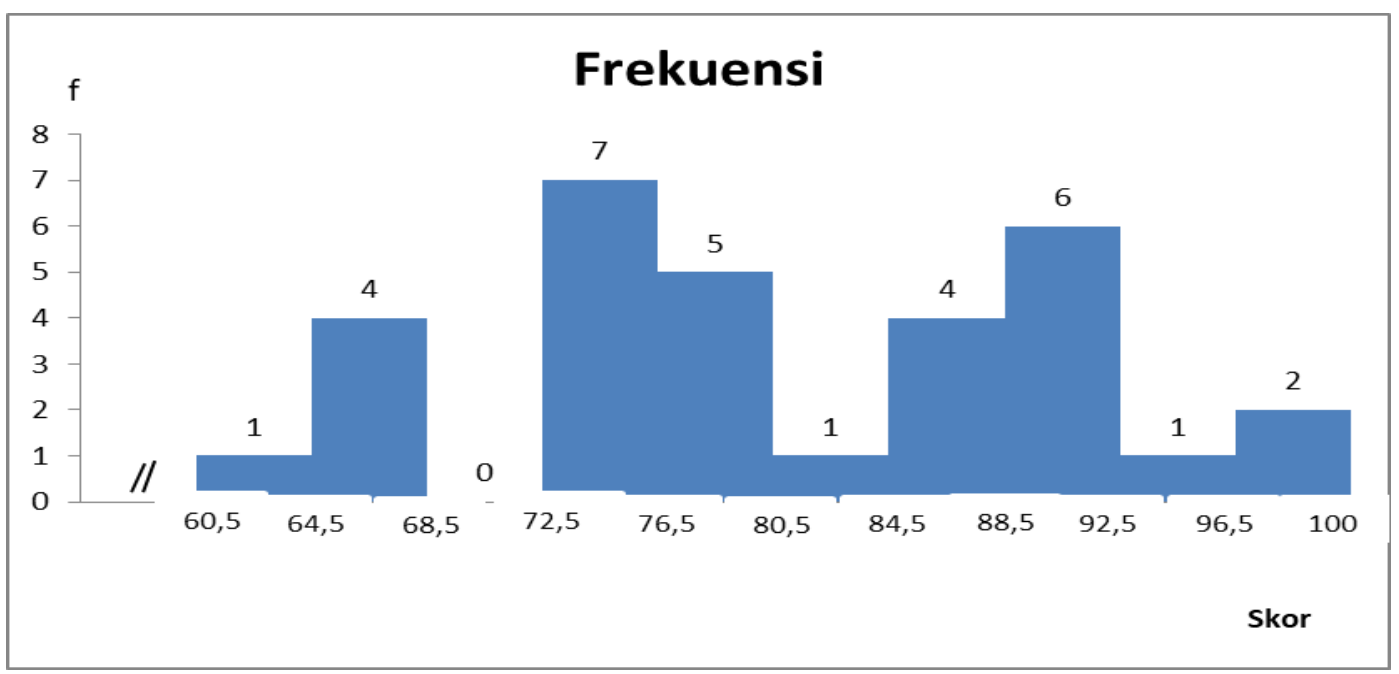

Gambar 3. Histogram Frekuensi Nilai Pembelajaran dengan Modul

b. Hasil Belajar Mata Pelajaran Autocad yang Dibelajarkan Tanpa Menggunakan Modul Pembelajaran

Berdasarkan penelitian yang ih dilakukan terhadap hasil belajar Autocad pada siswa yang dibelajarkan tanpa modul, ditemukan bahwa skor hasil belajar siswa dari 31 responden tersebar pada rentang $45-100$.
Dari hasil perhitungan menunjukan bahwa skor terendah 45 dan tertinggi 100 , mean 72,13 , median 178,65, dan standar deviasi 13,34. Secara lengkap gambaran tentang hasil belajar autocad siswa dengan menggunakan modul pembelajaran ditunjukkan pada tabel 5 . berikut ini:

Tabel 5. Frekuensi Nilai Hasil Belajar yang Dibelajarkan Dengan Menggunakan Modul

\begin{tabular}{|r|c|c|c|}
\hline No. & Skor & Frekuensi & Frekuensi Relatif (\%) \\
\hline 1 & $45-48$ & 1 & 3,23 \\
\hline 2 & $49-52$ & 2 & 6,45 \\
\hline 3 & $53-56$ & 3 & 9,68 \\
\hline 4 & $57-60$ & 3 & 9,68 \\
\hline 5 & $65-68$ & 6 & 19,35 \\
\hline 6 & $73-76$ & 4 & 12,9 \\
\hline 7 & $77-80$ & 6 & 19,35 \\
\hline 8 & $81-84$ & 1 & 3,23 \\
\hline 9 & $85-88$ & 2 & 6,45 \\
\hline 10 & $89-92$ & 2 & 6,45 \\
\hline 11 & $97-100$ & 1 & 3,23 \\
\hline & Rata-rata & 31 & 100 \\
\hline
\end{tabular}

Tabel 5. menunjukkan data hasil belajar autocad siswa yang dibelajarkan dengan menggunakan modul. Selanjutnya datas disusun dalam bentuk histogram seperti pada gambar 9 berikut ini: 


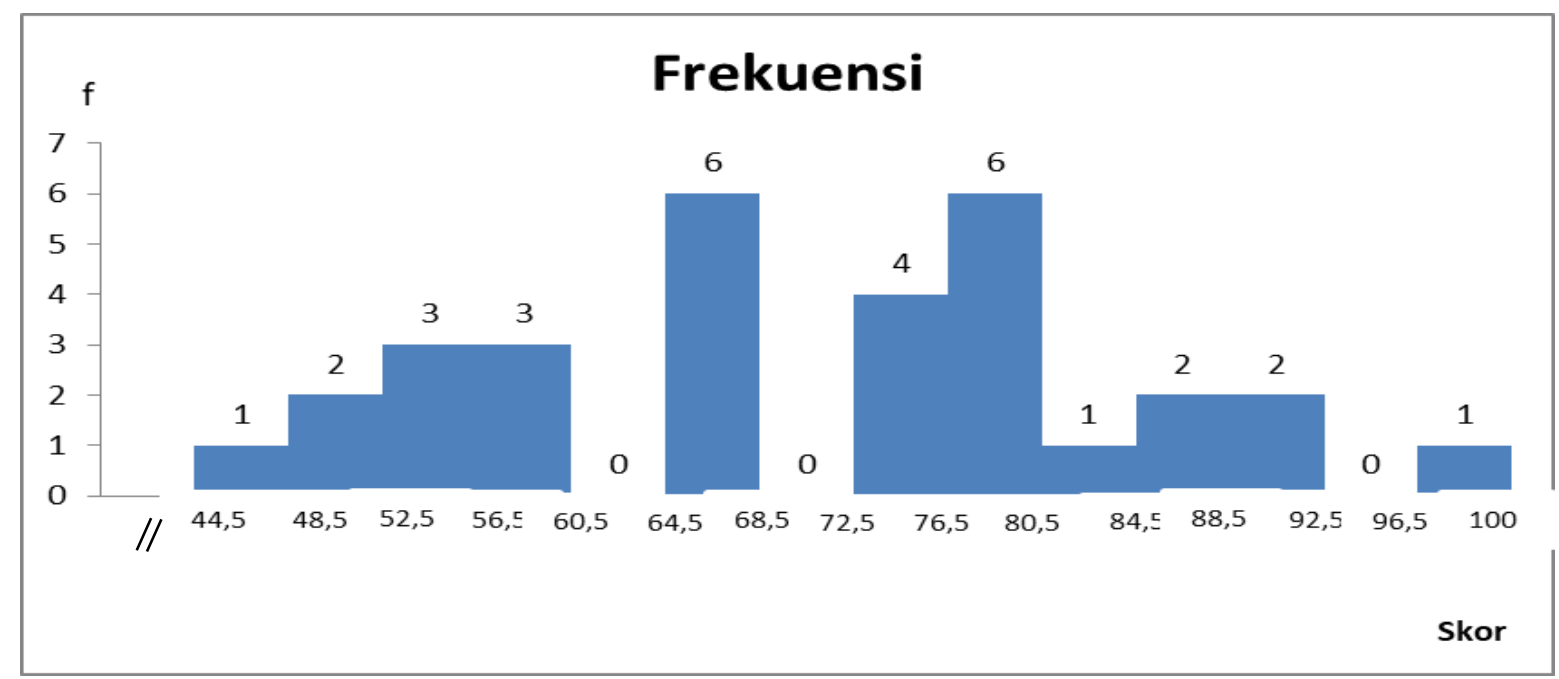

Gambar 4. Histogram Frekuensi Nilai Pembelajaran Tanpa Modul

\section{Pengajuan Persyaratan Analisis \\ a. Uji Normalitas Data \\ 1) Nilai Pretest}

Uji normalitas untuk mencari kenormalan dari sampel yang diteliti. Uji normalitas menggunakan rumus uji liliefors. Setelah dilakukan perhitungan, untuk kelas eksperimen diperoleh nilai $L_{0}=0,1119$.

Setelah membandingkan harga $L_{o}$ ini dengan harga Liliefors untuk $\mathrm{N}=31$ dan taraf nyata $\alpha=0,05$, diperoleh harga $L_{\text {tabel }}=0,1591$.

Ternyata $L_{0}<L_{\text {tabel }}$ berarti sampel berdistribusi normal.

Sedangkan uji normalitas nilai pretest untuk kelas kontrol diperoleh bahwa $L_{o}=0,1035$. Setelah membandingkan harga $L_{o}$ ini dengan harga Liliefors untuk $\mathrm{N}=31$ dan taraf nyata $\alpha=0,05$, diperoleh harga $L_{\text {tabel }}=0,1591$. Ternyata $L_{o}<L_{\text {tabel }}$ berarti sampel berdistribusi normal.

\section{2) Nilai Postest}

Setelah dilakukan perhitungan untuk kelas eksperimen diperoleh bahwa $L_{\circ}=$ 0,1138 . Setelah membandingkan harga $L_{o}$ ini dengan harga Liliefors untuk $\mathrm{N}=31$ dan taraf nyata $\alpha=0,05$, diperoleh harga $L_{\text {tabel }}=$ 0,1591 . Ternyata $L_{\circ}<L_{\text {tabel }}$ berarti sampel berdistribusi normal.

Sedangkan uji normalitas nilai posttest untuk kelas kontrol diperoleh bahwa $L_{o}=0,1539$. Setelah membandingkan harga $L_{o}$ ini dengan harga Liliefors untuk $\mathrm{N}=31$ dan taraf nyata $\alpha=0,05$, diperoleh harga
$L_{\text {tabel }}=0,1591$. Ternyata $L_{o}<L_{\text {tabel }}$ berarti sampel berdistribusi normal.

Berdasarkan uji normalitas kedua kelas di atas, maka disimpulkan bahwa seluruh populasi data penelitian berdistribusi normal. Perhitungan selengkapnya dapat dilihat pada lampiran 24 .

\section{b. Uji Normalitas Data}

Dari perhitungan uji homogenitas untuk nilai pretes diperoleh diperoleh $\mathrm{F}_{\text {hitung }}=$ 1,22 setelah membandingkan harga $F_{\text {hitung }}$ ini dengan harga table $F_{\text {tabel }}$ untuk $\mathrm{N}=31$ dan taraf nyata $\alpha=0,05$. Sehingga diperoleh $F_{\text {hitung }}<F_{\text {tabel }}$ yaitu $1,22<2,33$, maka dapat disimpulkan bahwa data dari kedua sampel untuk pretes atau sebelum perlakuan mempunyai varians yang sama.

Sedangkan dari perhitungan uji homogenitas untuk nilai postes diperoleh $\mathrm{F}_{\text {hitung }}=1,71$, sedangkan $\mathrm{F}_{\text {tabel }}$ diperoleh sebesar 2,23, maka dapat disimpulkan bahwa data dari kedua sampel untuk postes atau sesudah perlakuan mempunyai varians yang sama atau homogen. Selengkapnya lihat lampiran 25. Dengan demikian analisis dapat dilakukan.

\section{Pengujian Hipotesis}

Uji t dapat digunakan sebagai alat uji hipotesis karena data penelitian berdistribusi normal dan homogen. Hipotesis penelitian ini adalah sebagai berikut:

$\mathrm{Ha}$ : Modul pembelajaran yang dikembangkan mampu meningkatkan hasil belajar autocad. 


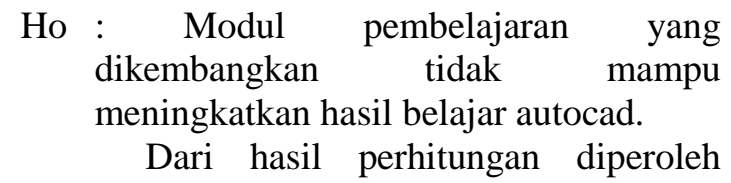
bahwa nilai $t_{\text {hitung }}$ sebesar 13,22 sedangkan $t$ table untuk $\mathrm{df}=62$ adalah 1,67. Oleh karena itu dapat disimpulkan bahwa $\mathrm{t}_{\text {hitung }}<\mathrm{t}$ table yang artinya $\mathrm{Ha}$ diterima yang berbunyi "Modul pembelajaran yang dikembangkan mampu meningkatkan hasil belajar autocad"

Keefektifan modul pembelajaran diperoleh dengan cara sebagai berikut:

$$
\mathrm{X}=\frac{\text { jumlahskor yang diperoleh }}{\text { jumlahskor ideal seluruh item }} \times 100 \%
$$

\section{PEMBAHASAN}

Dari paparan tentang pengertian hasil belajar yang dikemukakan diatas dapat dimaknai bahwa perubahan-perubahan dalam tingkah laku manusia dianggap sebagai hasil belajar yang mencakup aspek pengetahuan, keterampilan, sikap, dan nilai. Penilaian perubahan tingkah laku sebagai hasil belajar dapat dilakukan berdasarkan prinsip-prinsip: (a) kebutuhan yang ada pada diri organisme yang memungkinkan tumbuhnya tingkah laku yang bermotivasi, (b) motivasi yang mendasari perubahan tingkah laku itu, (c) tujuan yang mempengaruhi tingkah laku, (d) lingkungan yang menyediakan kesempatan untuk melakukan tingkah laku tertentu, (e) prosesproses yang mempengaruhi tingkah laku itu, (f) kapasitas dan kapabilitas yang mempengaruhi tingkah laku itu.

Belajar dapat diklasifikasi atas lima, yaitu kemampuan informasi verbal, keterampilan intelektual, strategi kognitif, keterampilan motorik, dan sikap. Kemampuankemampuan itu dihasilkan karena usaha belajar dan harus dibuktikan dari hasil belajar, siswa selalu dituntut untuk memberikan hasil belajar secara nyata. Hasil belajar akan nampak dalam prestasi belajar atau dalam produk yang dihasilkan oleh siswa.

Produk pengembangan modul pembelajaran pada mata diklat autocad merupakan materi pembelajaran yang telah dikembangkan dengan memperhatikan aspek pembelajaran. Penelitian pengembangan produk yang dilakukan ini diarahkan untuk menghasilkan suatu produk berupa modul pembelajaran pada mata diklat autocad untuk siswa SMk Negeri 1 Lubuk pakam Jurusan Teknik Gambar Bangunan kelas XI semester 4 yang digunakan untuk meningkatkan proses

$$
\begin{aligned}
& X=\frac{637}{775} \times 100 \% \\
& X=82,19 \%
\end{aligned}
$$

$$
\text { Nilai keefektifan modul }
$$

pembelajaran ini lebih tinggi dari nilai keefektifan pembelajaran tanpa modul yaitu sebesar yang diuraikan sebagai berikut:

$$
\begin{aligned}
& X=\frac{\text { jumlah skor yang diperoleh }}{\text { jumlah skor ideal seluruh item }} \times 100 \% \\
& X=\frac{559}{775} \times 100 \% \\
& X=\mathbf{7 2 , 1 3 \%}
\end{aligned}
$$

pembelajaran maupun kompetensi siswa. Oleh sebab itu proses penelitian dilakukan dan diawali dengan, (1) studi pendahuluan, (2) kemudian mendesain media pembelajaran, (3) melakukan validasi produk dan melakukan revisi dan penyempurnaan berdasarkan analisis data validasi dari ahli materi, (4) ahli desain pembelajaran yang dilanjutkan dengan ui coba perorangan, uji coba kelompok kecil, dan uji coba lapangan sehingga dihasilkan modul pembelajaran yang layak digunakan sesuai dengan karakteristik bidang studi dan siswa sebagai pengguna.

Aspek yang direvisi dan disempurnakan berdasarkan analisis data dan uji coba serta masukan dari ahli materi, dan ahli desain pembelajaran, dan siswa selaku pengguna modul pembelajaran, bertujuan untuk menggali beberapa aspek yang lazim dalam proses pengembangan suatu produk. Variable-variabel modul pembelajaran memiliki nilai rata-rata sangat baik.

Dari hasil pengolahan data penelitian yang dilakukan terhadap perbedaan hasil belajar mata diklat autocad antara siswa yang dibelajarkan dengan menggunakan modul pembelajaran dan siswa yang dibelajarkan dengan tanpa menggunakan modul pembelajaran yaitu rata-rata hasil belajar autocad siswa yang diajarkan dengan menggunakan modul pembelajaran lebih tinggi dibandingkan dengan siswa yang dibelajarkan tanpa modul pembelajaran. Hal ini dapat dilihat dari hasil rata-rata hasil belajar autocad siswa yang diajar dengan modul yaitu sebesar 82,19 $\%$, sedangkan hasil nilai rata-rata hasil belajar siswa yang diajarkan tanpa modul pembelajaran sebesar $72,13 \%$. Dari data ini membutikan bahwa penggunaan modul pembelajaran lebih baik dalam meningkatkan kompetensi dan 
pengetahuan siswa pada mata diklat autocad daripada tanpa menggunakan modul pembelajaran.

\section{PENUTUP}

1. Hasil menunjukkan bahwa: (1) Hasil validasi dari ahli materi terhadap modul pembelajaran pada mata diklat autocad yang dikembangkan secara keseluruhan termasuk kategori "Sangat Baik"; (2) Hasil validasi dari ahli desain pembelajaran terhadap modul pembelajaran pada mata diklat autocad yang dikembangkan termsasuk kategori sangat baik sehingga dapat diterima dan layak digunakan dalam proses pembelajaran; (2) Menurut tanggapan siswa SMK Negeri Lubuk Pakam Jurusan Teknik Gambar Bangunan pada uji coba perorangan dinyatakan bahwa modul pembelajaran termasuk kategori sangat baik; (3) Menurut tanggapan siswa SMK Negeri Lubuk Pakam Jurusan Teknik Gambar Bangunan pada uji coba kelompok kecil dinyatakan bahwa modul pembelajaran termasuk kategori sangat baik; (4) Menurut tanggapan siswa SMK Negeri Lubuk Pakam Jurusan Teknik Gambar Bangunan pada uji coba lapangan dinyatakan bahwa modul pembelajaran termasuk kategori sangat baik.

2. hasil belajar siswa yang dibelajarkan dengan menggunakan modul pembelajaran dengan hasil belajar siswa yang dibelajarkan dengan metode ceramah. Dan Modul pembelajaran memiliki keefektifan lebih tinggi dari keefektifan dengan metodeh ceramah.

\section{DAFTAR PUSTAKA}

AECT. (1977). Definisi Teknologi Pendidikan (Satuan Tugas Definisi \& Termitologi AECT). Jakarta. Rajawali

Chandra, H. (2003). 36 Jam Belajar Komputer Dasar-Dasar AutoCAD 2000. Jakarta. Alex Media Komputindo.
Dalyono, M. (2003). Psikologi Pendidikan. Jakarta. Rineka Cipta

Dick, W. dan Carey, L. (1996). The Systematics Design Of Instruction. New York : Longman

Hamalik, O. (1999). Kurikulum dan Pembelajaran. Jakarta: Bumi Aksara.

Miarso, Yusufhadi. 2004. Menyemai Benih Teknologi Pendidikan. Jakarta: Prenada Media dan Pustekkom Diknas.

Muhibinsyah. (2010). Psikologi Belajar. Jakarta: Bumi Aksara.

Munadi, Y. (2013). Media Pembelajaran (Sebuah Pendekatan Baru). Jakarta.

Nasution, S. (2008). Proses Belajar Mengajar. Jakarta: Bumi Aksara.

Rorry, R. (2012). Jurus Kilat Mahir Autocad. Bandung. Dunia Komputer

Sanusi, M.(2008). Kreasi Desain Produk Distro dan Fashion 3D. Jakarta. Alex Media Komputindo.

Seels, B.B. S. Richey, R.C. 1994. Instruktional Technology: The Definition and Domains of the Field. Washington DC : Association for Educational Communicational and Technology.

Sibuea, A.M. (2000). Pengajaran Dengan Modul Berdasarkan Kompetensi. Medan: Jurnal Pengabdian Kepada Masyarakat UNIMED. Vol.6.No.22.Th.VI.

Slameto. (2003). Belajar dan Faktor-faktor yang Mempengaruhinya. Jakarta: Rineka Cipta.

Soekamto, T. (1993). Perancangan dan Pengembangan Sistem Instruksional. Jakarta: Intermedia.

Sudjana. (2002). Metode Statika. Bandung: Tarsito.

Sugianto, M. (2010). Merancang Perkantoran dan Perumahan Menggunakan Autocad 2010. Yogyakarta. Andi.

Sugiyono. 2008. Metode Penelitian Pendidikan (Pendekatan Kuantitatif, Kualitatif, dan $R \& D)$. Bandung : CV. Alfabeta. 